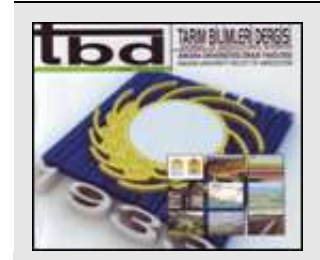

Tarım Bilimleri Dergisi

Journal of Agricultural Sciences

Tar. Bil. Der.

Dergi web sayfası:

www.agri.ankara.edu.tr/dergi

Journal homepage:

www.agri.ankara.edu.tr/journal

\title{
Effect of Fertilization on Weed Infestation, Morphological and Productive Traits of Different Alternative Small Grains
}

\author{
Svetlana ROLJEVIĆ NIKOLIĆa, Dušan KOVAČEVIĆb, Željko DOLIJANOVIĆb, Rajko MIODRAGOVIĆc \\ Aleksandar KOVAČEVIĆb

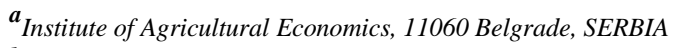

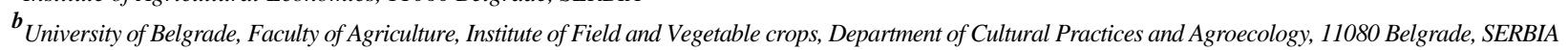

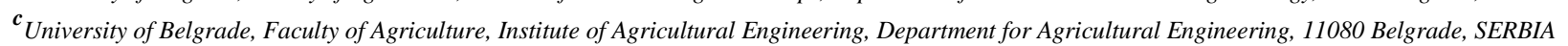

\author{
ARTICLE INFO \\ Research Article \\ Corresponding Author: Željko DOLIJANOVIĆ, E-mail: dolijan@agrif.bg.ac.rs, Tel: +381 114413321 \\ Received: 10 April 2019, Received in Revised Form: 28 June 2019, Accepted: 09 July 2019
}

\section{AUTHORS ORCID ID:}

(Svetlana ROLJEVIĆ NIKOLIĆ: (0000-0002-3139-0289), (Dušan KOVAČEVIĆ: 0000-0002-7471-8707), (Željko DOLIJANOVIĆ: 00000002-9224-3274), (Rajko MIODRAGOVIĆ: 0000-0002-8222-9719), (Aleksandar KOVAČEVIĆ: 0000-0001-7973-7731)

\begin{abstract}
This examination aims to determinate influence of fertilizers toward weed infestation, morphological and productive traits of different alternative small grains, as well as to examine the correlation of the studied traits of alternative small grains with weed infestation in organic production. The field experiment was conducted on luvic chernozem in completely randomized blocks, repeatad four times, in the three year period (2013/2014-2015/2016). Examination was carried out on one winter cultivars of naked barley, spelt, durum, compactum wheat and triticale, and the experiment included fertilization with microbiological fertilizer $\left(5.0 \mathrm{~L} \mathrm{ha}^{-1}\right)$ as well as the combined application of microbiological $\left(5.0 \mathrm{~L} \mathrm{ha}^{-1}\right)$ and organic fertilizer $\left(3.0 \mathrm{t} \mathrm{ha}^{-1}\right)$. Results obtained pointed out that examined factors have important influence toward number and the dry weed weight, but the influence toward diversity weeds is negligible. The smallest the total number of weeds $\left(12.7\right.$ plants $\left.\mathrm{m}^{-2}\right)$, as well as the
\end{abstract}

Keywords: Alternative small grains; Organic farming; Fertilizers; Weed infestation

\section{Introduction}

(C) Ankara Üniversitesi Ziraat Fakültesi

The selection of species and cultivars of cereals suitable to specific conditions of organic agriculture demands different approach comparing to that used in conventional and intensive system of production (Przystalski et al 2008; Roljevic Nikolic et al 2018). This is because there are fewer opportunities in organic production to compensate for yield decrease caused by diseases, low nutrient levels, and weeds (Wolfe et al 2008). An important part of the weed control strategy in the organic production system is the selection of cultivars that compete with weeds for limited resources, produce exudates that inhibit growth of weeds and reduce economic losses by maintaining a high level of grain yield (Andrew et al 2015). During the last three decades the significant development was achieved in understanding the morphological and physiological traits of cereals which provide foundation for their competitive ability against weeds. Examinations conducted globally are pointing toward those cereal`s cultivars with fast initial growth, height of stem, large leaf surface and intensive tillering, to be the most competitive. It is determined that such a varietes are reducing the photosyntetic active radiation through their above-ground parts, creating shade for weeds and thus reducing their biomass and number 
(Korres \& Froud-Williams 2002; Vandeleur \& Gill 2004; Mason et al 2007; Zerner et al 2016). Therefore, the imperatives in organic production is knowledge of crop characteristics in order to establish stable production.

Apart from genotype, soil fertility and availability of nutrients can also affect the diversity and dynamics of the weed community (Jornsgard et al 1996; Blackshaw et al 2005). Garcia-Martin et al (2007) have noted that by reducing the availability of nutrients in the initial stages of vegetation, weeds are placed in an extremely unfavorable position in relation to crops, and in this respect organic sources of nutrients can have an impact on the weed community.

On the other hand, some studies conducted with mineral fertilizers have shown that higher levels of their application positively affect the seed germination (Jornsgard et al 1996) and the weed number (Ross \& Van Acker 2005), and that the mineral fertilization have a stimulating effect on weed infestation. When it comes to weed biomass, Jornsgard et al (1996) state that weed biomass in winter wheat could be increased, unchanged, or reduced with increased soil $\mathrm{N}$ depending on weed and crop. The aim of this research is to determine if in the terms of organic production, the use of fertilization might influence weed infestation, morphological and productive traits of alternative small grains, simulatenously, investigate connection between traits of different alternative small grains and the weed infestation.

\section{Material and Methods}

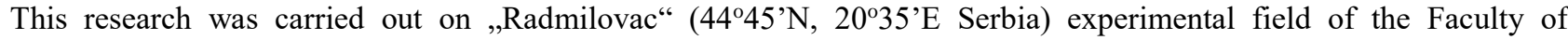
Agriculture in Belgrade, during the period 2013/2014-2015/2016. The average annual air temperature in this period was $12.7^{\circ} \mathrm{C}$, while the average rainfall was $670.6 \mathrm{~mm}$.

A two-factor field trial was arranged using the completely randomized blocks was employed in four replications, with the area of the elementary plot amounting to $6 \mathrm{~m}^{2}$. The soil type was luvic chernozem (WRB 2014), with the following characteristics: $\mathrm{pH}-\left(\mathrm{H}_{2} \mathrm{O}\right) 8.04$, total content of $\mathrm{N} 13 \%$, available forms of phosphorus $22.18 \mathrm{mg}_{2} \mathrm{P}_{5} 100 \mathrm{~g}^{-1}$ dry weight and potassium $19.10 \mathrm{mg} \mathrm{K}_{2} \mathrm{O} 100 \mathrm{~g}^{-1} \mathrm{dw}$, content of humus in the topsoil layer $2.45 \%$. Winter cultivars of different alternative small grains are grown in four crop rotation: maize $\rightarrow$ winter wheat $\rightarrow$ spring barley+red clover $\rightarrow$ red clover. Previous crop was maize (Zea mays L.) in all three seasons.

Tillage method with the plough was carried out at a depth of $25 \mathrm{~cm}$, from 15-20 October during all three years. Presowing preparation was carried out by disc harrow and harrow. The sowing was done manually, from 20-25 October.

The examined factors were different species of alternative small grains and fertilization. Five domestic cultivars of different alternative small grains are included in this research: Hordeum vulgare var. nudum (cv. Golijat, 450 seeds m$^{-2}$ ); Triticum durum (cv. Dolap, 600 seeds $\mathrm{m}^{-2}$ ); Triticum aestivum ssp. compactum (cv. Bambi, 600 seeds $\mathrm{m}^{-2}$ ); Triticum aestivum ssp. spelta (cv. Nirvana, 550 seeds $\mathrm{m}^{-2}$ ); Triticale sp. (cv. Odisej, 550 seeds $\mathrm{m}^{-2}$ ).

Two varinats of fertilization were applied: $\mathrm{F}_{1}$ - application of foliar microbiological fertilizer in the spring, in phenofase BBCH 31-33 (5.0 $\left.\mathrm{L} \mathrm{ha}^{-1}\right), \mathrm{F}_{2}$ - ploughing under biohumus in autumn $\left(3.0 \mathrm{t} \mathrm{ha}^{-1}\right)$ and application of foliar microbiological fertilizer in the spring in phenofase BBCH 31-33 $\left(5.0 \mathrm{~L} \mathrm{ha}^{-1}\right)$. Control $\left(\mathrm{F}_{0}\right)$ was without of fertilizer. Properties of organic fertilizer (commercial name „Biohumus Royal offert“, producer „Altamed“ Serbia) was: $\mathrm{pH} 8.63$, minimum content of: N 2.2\%. $\mathrm{P}_{2} \mathrm{O}_{5} 4.8 \%$ and $\mathrm{K}_{2} \mathrm{O} 2.8 \%$. Features of microbiological fertilizer (commercial name „Slavol“, producer „Agrounik“ Serbia) was: Bacillus megaterium $10^{-6} \mathrm{~cm}^{3}$, Bacillus licheniformis $10^{-6} \mathrm{~cm}^{3}$, Bacillus suptilis $10^{-6} \mathrm{~cm}^{3}$, Azotobacter chtoococcum $10^{-6} \mathrm{~cm}^{3}$, Azotobacter vinelandi $10^{-6} \mathrm{~cm}^{3}$, Derxia sp. $10^{6} \mathrm{~cm}^{3}$.

Weed infestation is followed by: floristic composition of weed community, number of perennial species and number of annual species (species $\mathrm{m}^{-2}$ ), number od weeds (plants $\mathrm{m}^{-2}$ ) and dry weed weight $\left(\mathrm{g} \mathrm{m}^{-2}\right)$ noticed during the whole examined period. The floristic composition of weed community is determined by method of squared before small grains heading.

Weeds were cut and roots discarded. The weight was measured $\left(\mathrm{g} \mathrm{m}^{-2}\right)$ in fresh, and after drying in natural conditions, along with the weight in air dry condition. Measures for weed suppression were not carried out.

During all three years of examination, seven to ten days before harvest, 10 plants were randomly sampled in order to determine the morphological and productive traits of all alternative small grains in each variant of fertilization. The 
following parameters were measured: (1) the stem height to the spike (cm), (2) the length of the spike (cm), (3) the weight of stem and the spike-weight of plants (g), (4) the weight of grains per spike (g).

Data processing was performed in Statistica statistical package. A method for analyzing variance $(F$ test $)$ for dual factor examination was used, and the significance of differences between treatments was tested with the LSD test at significance level $\mathrm{P}<0.01$ and $\mathrm{P}<0.05$. The method of simple linear correlation and regression analysis was used to examine the dependence between the parameters tested.

\section{Results and Discussion}

\subsection{Floristic composition of weed community of diferent alternative small grains in organic production}

After the observation during this three-year period, it can be concluded that a weed community consists of relatively large number of species (26) in alternative small grains, representing one of organic field production characteristics. Annual weeds make $61.5 \%$, and perennial $38.5 \%$ of the total number of recorded species. According to Koocheki et al (2009), in organic and rational crop cultivation systems, perennial weeds account for $66 \%$ and $56 \%$ of the total weed population, while in intensive crop cultivation systems they are significantly lower. During all three years of the examined period, preceding crop was maize (Zea mays L), row crop, thus explaining the higher representation of annual weeds. The most prevalent annual weed are Stellaria media (L.) Vill., Veronica persica Poir., Capsella bursa pastoris L., and perennial Agropyrum repens L., Lepidim draba L. and Convolvulus arvensis L. (Table 1). These weed species infestate a lot of various crops, particularly cereals and row crops.

Table 1- Floristic composition of weed community in cereals

\begin{tabular}{|c|c|c|c|}
\hline \multirow{2}{*}{ Weed species } & \multicolumn{3}{|c|}{ Fertilization } \\
\hline & $F_{0}$ & $F_{1}$ & $F_{2}$ \\
\hline \multicolumn{4}{|l|}{ Annual weeds $\left(\mathrm{m}^{-2}\right)$} \\
\hline Apium graveolens L. & 2.0 & & 2.0 \\
\hline Ambrosia artemisiifolia L. & 3.3 & & 1.5 \\
\hline Avena fatua $\mathrm{L}$. & 2.8 & 3.0 & \\
\hline Bilderdykia convolvulus (L.) Dum. & 2.0 & 2.0 & 1.9 \\
\hline Capsella bursa pastoris (L.) Medic. & 2.5 & 2.3 & 2.3 \\
\hline Chamomila recutita $\mathrm{L}$. & 1.5 & 1.5 & 1.0 \\
\hline Chenopodium album L. & & 2.0 & 1.8 \\
\hline Consolida regalis S.F. Gray & 2.5 & 2.0 & 1.0 \\
\hline Erigeron canadensis L. & 1.5 & 1.8 & 1.5 \\
\hline Galium aparine L. & & & 2.0 \\
\hline Papaver rhoeas $\mathrm{L}$. & & 1.0 & 2.0 \\
\hline Polygonum aviculare L. & 1.8 & 2.5 & 2.0 \\
\hline Sinapis arvensis L. & 2.1 & 2.7 & 1.6 \\
\hline Sonchus oleraceus L. & 1.5 & 2.0 & 1.9 \\
\hline Stellaria media (L.) Vill. & 3.2 & 4.3 & 3.9 \\
\hline Veronica persica Poir. & 4.6 & 2.5 & 3.4 \\
\hline \multicolumn{4}{|l|}{ Perennial weeds $\left(\mathrm{m}^{-2}\right)$} \\
\hline Agropyrum repens (L.) Beauv. & 5.3 & 2.3 & 6.0 \\
\hline Cirsium arvense (L.) Scop. & 2.0 & 2.9 & 3.3 \\
\hline Convolvulus arvensis L. & 4.3 & 2.5 & 3.2 \\
\hline Euphorbia cyparissias L. & 1.0 & & \\
\hline Lepidium draba L. & 5.0 & 2.8 & 3.5 \\
\hline Rubus caesius L. & & & 3.0 \\
\hline Sonchus arvensis L. & 1.8 & 2.0 & \\
\hline Sorghum halepense (L.) Pers. & 1.5 & 1.0 & 2.3 \\
\hline Taraxacum officinale Weber. & 3.0 & & 1.0 \\
\hline Trifolium pratense L. & 3.0 & 3.1 & 3.0 \\
\hline Total number of weed species & 22 & 20 & 23 \\
\hline Total number of weeds (no. $\mathrm{m}^{-2}$ ) & 58.1 & 46.1 & 55.1 \\
\hline Number of annual weeds (no. $\mathrm{m}^{-2}$ ) & 31.3 & 29.6 & 29.8 \\
\hline Number of perennial weeds (no. $\mathrm{m}^{-2}$ ) & 26.8 & 16.5 & 25.3 \\
\hline Dry weed weight $\left(\mathrm{g} \mathrm{m}^{-2}\right)$ & 20.7 & 23.7 & 23.8 \\
\hline
\end{tabular}


The proper selection of species and cultivars of crops is an important part of the strategy in the action against weeds, especially in production systems characterized by reduced protection (Andruszczak et al 2012; Andrew et al 2015). The results of the study have shown that the genotype has a slight influence on the diversity of the weed community in conditions of organic production. Only statistically significant differences in the number of perennial weeds were established, whereby it is with the spelt $\left(0.9\right.$ species $\left.\mathrm{m}^{-2}\right)$ significantly lower compared to triticale $\left(2.0\right.$ species $\left.\mathrm{m}^{-2}\right)$ and compactum wheat (1.8 species $\mathrm{m}^{-2}$ ) (Table 2). Examining the impact of different tillage methods on the weed community in organic production Sans et al (2011) have established a smaller share of perennial weeds in the crop of spelt compared to common wheat. Research conducted by other authors is also indicative of the lesser weed infestation of spelt compared to other cereals (Szewczyk 2013).

Table 2- Weed infestation of winter cultivars various cereals

\begin{tabular}{|c|c|c|c|c|c|c|c|c|}
\hline \multirow{2}{*}{$\begin{array}{l}\text { Fertilizer } \\
\text { Genotype }\end{array}$} & $F_{O}$ & $F_{1}$ & $F_{2}$ & \multirow[b]{2}{*}{ Average } & $F_{O}$ & $F_{1}$ & $F_{2}$ & \multirow[b]{2}{*}{ Average } \\
\hline & \multicolumn{3}{|c|}{$\begin{array}{l}\text { The number of perennial weeds } \\
\left(\text { species } \mathrm{m}^{-2}\right)\end{array}$} & & \multicolumn{3}{|c|}{$\begin{array}{l}\text { The number of annual weeds } \\
\left(\text { species } m^{-2}\right)\end{array}$} & \\
\hline Golijat & 1.5 & 0.7 & 1.8 & 1.3 & 4.3 & 4.8 & 4.3 & 4.4 \\
\hline Dolap & 1.2 & 2.3 & 1.5 & 1.6 & 4.5 & 3.0 & 4.0 & 3.8 \\
\hline Bambi & 1.8 & 2.0 & 1.5 & 1.8 & 3.8 & 3.8 & 4.3 & 3.9 \\
\hline Nirvana & 0.6 & 1.8 & 0.5 & 0.9 & 3.5 & 4.0 & 4.3 & 3.9 \\
\hline Odisej & 1.4 & 2.1 & 2.5 & 2.0 & 3.8 & 3.5 & 3.8 & 3.7 \\
\hline \multirow[t]{2}{*}{ Average } & 1.3 & 1.8 & 1.6 & & 3.9 & 3.8 & 4.1 & \\
\hline & \multicolumn{3}{|c|}{$\begin{array}{l}\text { The total number of weeds } \\
\left(\text { plants } m^{-2}\right)\end{array}$} & Average & \multicolumn{3}{|c|}{ Dry weed weight $\left(\mathrm{g} \mathrm{m}^{-2}\right)$} & Average \\
\hline Golijat & 15.5 & 18.8 & 15.5 & 16.6 & 24.9 & 26.2 & 25.0 & 25.4 \\
\hline Dolap & 16.6 & 18.5 & 15.5 & 16.7 & 30.8 & 21.9 & 26.1 & 26.2 \\
\hline Bambi & 14.3 & 13.5 & 14.8 & 14.2 & 13.6 & 21.9 & 25.2 & 20.2 \\
\hline Nirvana & 13.3 & 12.8 & 12.0 & 12.7 & 12.1 & 18.0 & 25.4 & 18.5 \\
\hline Odisej & 18.3 & 13.5 & 15.5 & 15.8 & 22.2 & 30.2 & 17.3 & 23.3 \\
\hline Average & 15.5 & 15.4 & 14.7 & & 20.7 & 23.7 & 23.8 & \\
\hline
\end{tabular}

On the other hand, the number of weeds and their dry weight was significantly influenced by investigated factors as their interaction is producing significant effect (Table 3). The results indicate significant differences between the alternative small grains in the number of weeds, with the largest number being recorded in durum wheat $\left(16.7 \mathrm{plants}^{-2}\right)$ and the lowest in spelt (12.7 plants $\mathrm{m}^{-2}$ ) (Table 2). A significant influence of fertilization on the total number of weeds was determined, whereby it smaller on the variant $F_{2}\left(14.7\right.$ plants $\left.\mathrm{m}^{-2}\right)$ compared to $\mathrm{F}_{1}\left(15.4\right.$ plants $\left.\mathrm{m}^{-2}\right)$ and $\mathrm{F}_{0}(15.5$ plants $\left.\mathrm{m}^{-2}\right)(\mathrm{P}<0.05)$. In these production conditions, the $\mathrm{GxF}$ interaction showed a very significant impact on the number of weeds, which was most pronounced in triticale, as the number of weeds on varieties $F_{1}$ and $F_{2}$ was $26.2 \%$ and $15.3 \%$ lower compared to control. On the other hand, in naked barley and durum wheat number of weeds at $\mathrm{F}_{1}$ variant was significantly higher in comparison with the $\mathrm{F}_{0}(21.3 \%$ and $11.4 \%)$, while in spelt and compactum wheat the obtained differences between the variants of fertilization were not significant.

During the examination of weed infestation among crops of winter spelt wheat cultivars grown under different conditions of mineral fertilization and chemical plant protection, Andruszczak et al (2012) have underlined that application of higher rates of mineral fertilizers have slightly increased the number of weeds. Similar results are noticed by other authors (Jornsgard et al 1996).

The analysis of the variance of dry weeds weight indicates that there are very significant differences between the investigated genotypes (Table 3). The highest dry weight of the weed was recorded in durum wheat $\left(26.2 \mathrm{~g} \mathrm{~m}^{-2}\right)$, and the lowest in the spelt $\left(18.5 \mathrm{~g} \mathrm{~m}^{-2}\right)$ (Table 2). A large dry weight of the weed recorded in the cv. Dolap was expected, given the origin of durum wheat and its adaptation to a warmer climate with less precipitation (Kaya \& Turkoz 2016). On the other hand, examinations of other authors also indicate the high competitiveness of spelt against weeds in conventional (Andruszczak et al 2012; Szewczyk 2013) and organic production (Zuk-Golaszewska et al 2015).

Fertilization is a factor that significantly affects the weeds weight (Table 3). Very significant differences were found between control $\left(20.7 \mathrm{~g} \mathrm{~m}^{-2}\right)$ and fertilization variants $\left(23.7 \mathrm{~g} \mathrm{~m}^{-2}\right.$ and $\left.23.8 \mathrm{~g} \mathrm{~m}^{-2}\right)$ (Table 2). Also, the obtained 
differences between fertilization variants in the examined alternative small grains were significant (GxF) (Table 2 and Table 3). The largest differences were found in the compactum wheat and spelt, wherein the dry weight of the weed on the $\mathrm{F}_{1}$ variant was higher by $61.0 \%$ and $48.8 \%$, while in the variant $\mathrm{F}_{2}$ to $85.3 \%$ and $109.9 \%$ compared to control. Significantly lower dry weight of the weed on varieties with applied fertilizers compared to control was recorded only in hard wheat $(28.9 \%$ and $15.3 \%)$. On the other hand, some authors have not noticed significant differences in the biomass of weeds between different levels of mineral fertilizers, because in such circumstances it was dependent on both crops and the types of weeds (Jornsgard et al 1996; Andruszczak et al 2012).

Table 3- The statistical significance of differences of the tested parameters ( $F$ test and LSD test)

\begin{tabular}{|c|c|c|c|c|c|}
\hline \multirow{4}{*}{$\begin{array}{l}\text { Parameters } \\
\text { The number of } \\
\text { perennial weeds } \\
\left(\text { species } \mathrm{m}^{-2}\right)\end{array}$} & \multicolumn{2}{|c|}{ Factor/Interaction } & \multirow{2}{*}{$\begin{array}{l}G \\
*\end{array}$} & \multirow{2}{*}{$\begin{array}{l}F \\
\text { ns }\end{array}$} & \multirow{2}{*}{$\begin{array}{l}G x F \\
\text { ns }\end{array}$} \\
\hline & $F$ test & & & & \\
\hline & LSD & 0.05 & 0.725 & - & - \\
\hline & & 0.01 & 0.994 & - & - \\
\hline \multirow{3}{*}{$\begin{array}{l}\text { The number of } \\
\text { annual weeds } \\
\left(\text { species } \mathrm{m}^{-2} \text { ) }\right.\end{array}$} & $F$ test & & $\mathrm{ns}$ & $\mathrm{ns}$ & ns \\
\hline & LSD & 0.05 & - & - & - \\
\hline & & 0.01 & - & - & - \\
\hline \multirow{3}{*}{$\begin{array}{l}\text { The total number } \\
\text { of weeds } \\
\left(\text { plants } \mathrm{m}^{-2} \text { ) }\right.\end{array}$} & $F$ test & & $* *$ & $*$ & $* *$ \\
\hline & LSD & 0.05 & 0.828 & 0.642 & 1.435 \\
\hline & & 0.01 & 1.136 & 0.880 & 1.967 \\
\hline \multirow{3}{*}{$\begin{array}{l}\text { Dry weed } \\
\text { weight } \\
\left(\mathrm{g} \mathrm{m}^{-2}\right)\end{array}$} & $F$ test & & $* *$ & $* *$ & $* *$ \\
\hline & LSD & 0.05 & 0.433 & 0.612 & 0.866 \\
\hline & & 0.01 & 0.594 & 0.840 & 1.187 \\
\hline \multirow{3}{*}{$\begin{array}{l}\text { Stem height } \\
(\mathrm{cm})\end{array}$} & $F$ test & & $* *$ & $* *$ & ns \\
\hline & LSD & 0.05 & 2.178 & 3.080 & - \\
\hline & & 0.01 & 2.986 & 4.223 & - \\
\hline \multirow{3}{*}{$\begin{array}{l}\text { Spike length } \\
(\mathrm{cm})\end{array}$} & $F$ test & & $* *$ & $* *$ & ns \\
\hline & LSD & 0.05 & 0.280 & 0.396 & - \\
\hline & & 0.01 & 0.384 & 0.543 & - \\
\hline \multirow{3}{*}{$\begin{array}{l}\text { Weight stem } \\
\text { and length } \\
\text { (g) }\end{array}$} & $F$ test & & $* *$ & $* *$ & ns \\
\hline & LSD & 0.05 & 0.198 & 0.280 & - \\
\hline & & 0.01 & 0.271 & 0.384 & - \\
\hline \multirow{3}{*}{$\begin{array}{l}\text { Weight of } \\
\text { grains per spike } \\
\text { (g) }\end{array}$} & $F$ test & & $* *$ & $* *$ & $\mathrm{~ns}$ \\
\hline & & 0.05 & 0.07 & 0.09 & - \\
\hline & & 0.01 & 0.09 & 0.13 & - \\
\hline
\end{tabular}

G-genotypes (Golijat, Dolap, Bambi, Nirvana, Odisej); F-fertilizers ( $F_{0}$ control, $F_{1}$ microbiological fertilizer, $F_{2}$ organic + microbiological fertilizer); ns, $\mathrm{P}>0.05, *, \mathrm{P}<0.05, * *, \mathrm{P}<0.01$

\subsection{Morphological and productive traits of different alternative small grains in organic production}

The height of the stem, as well as the overall height of the plant, represents an important traits for cereals, significantly influencing the formation of total yield (Zerner et al 2016). In the framework of the investigated alternative small grains, the spelt is distinguished by the highest stem $(94.2 \mathrm{~cm})$ and the longest spike $(10.3 \mathrm{~cm})$. The largest plant weight and grain weight in the spike were recorded in triticale, cv. Odisej $(4.1 \mathrm{~g}$ and $1.6 \mathrm{~g})$. On the other hand, the weight of the plant $(2.0 \mathrm{~g})$ and the grain weight in the spike $(0.9 \mathrm{~g})$ of naked barley (cv. Golijat), is significantly lower compared to other genotypes (Table 4).

Significant differences in the investigated traits were also established between fertilization variants. The use of fertilizers significantly influenced the increase in the height of the stem (5.5-10.0\%), the length of the spike (6.4-9.9\%), the plant weight $(9.5-20.8 \%)$ and the grain weight in the spike (7.8-16.9\%), in particular the variant $\mathrm{F}_{2}$. JablonskyteRašče et al (2013) have found that the combined application of organic fertilizer and bio-activators significantly affects 
the length and weight of spike of common and compactum wheat. Significantly higher weight of grains per spike wheat on intensively fertilized treatments was obtained by Jaćimović et al (2008).

Table 4- Morphological and productive traits of winter cultivars tested cereals

\begin{tabular}{|c|c|c|c|c|c|c|c|c|}
\hline Fertilizer & $F_{O}$ & $F_{1}$ & $F_{2}$ & \multirow{2}{*}{ Average } & $F_{O}$ & $F_{I}$ & $F_{2}$ & \multirow{2}{*}{ Average } \\
\hline Genotype & \multicolumn{3}{|c|}{ Stem height $(\mathrm{cm})$} & & \multicolumn{3}{|c|}{ Spike length $(\mathrm{cm})$} & \\
\hline Golijat & 55.6 & 59.3 & 62.1 & 59.0 & 8.5 & 9.5 & 9.6 & 9.2 \\
\hline Dolap & 63.7 & 64.9 & 67.2 & 65.3 & 6.7 & 6.8 & 6.9 & 6.8 \\
\hline Bambi & 74.0 & 81.8 & 84.8 & 80.2 & 4.0 & 4.1 & 4.1 & 4.1 \\
\hline Nirvana & 90.8 & 93.1 & 98.8 & 94.2 & 9.7 & 10.2 & 10.8 & 10.3 \\
\hline Odisej & 73.7 & 78.3 & 80.8 & 77.6 & 9.4 & 10.1 & 10.6 & 10.0 \\
\hline \multirow[t]{2}{*}{ Average } & 71.6 & 75.5 & 78.7 & & 7.7 & 8.1 & 8.4 & \\
\hline & \multicolumn{3}{|c|}{ Weight stem and length $(g)$} & Average & \multicolumn{3}{|c|}{ Weight of grains per spike $(g)$} & Average \\
\hline Golijat & 1.9 & 2.0 & 2.1 & 2.0 & 0.9 & 0.9 & 0.9 & 0.9 \\
\hline Dolap & 2.9 & 3.1 & 3.4 & 3.1 & 1.3 & 1.4 & 1.6 & 1.4 \\
\hline Bambi & 3.3 & 3.7 & 4.0 & 3.7 & 1.4 & 1.5 & 1.6 & 1.5 \\
\hline Nirvana & 2.8 & 2.9 & 3.3 & 3.0 & 1.3 & 1.4 & 1.6 & 1.4 \\
\hline Odisej & 3.6 & 4.1 & 4.7 & 4.1 & 1.5 & 1.6 & 1.8 & 1.6 \\
\hline Average & 2.9 & 3.2 & 3.5 & & 1.3 & 1.4 & 1.5 & \\
\hline
\end{tabular}

Although the GxF interaction did not have a significant impact on the examined morphological and productive traits, the application of fertilizers showed a positive effect on all types of alternative small grains. The best effect of fertilization on the stem height, the weight stem and length, as well as the weight of grains per spike was found in the compactum wheat, while the biggest difference between fertilization variants in the spike length was recorded in the naked barley.

\subsection{Correlation and regression analysis}

The results of the correlation analysis indicate a positive correlation between the morphological and productive properties of alternative small grains (Table 5). In addition, the negative correlation between the height stem and the number of weeds $\mathrm{m}^{-2}(-0.69)$, as well as the dry weeds weigh $(-0.39)$ is noticed. Regression analysis is often used biostatistik technique in plant breeding (Pakize et al 2015). Based on the regression equation, it was found that the increase in the height stem by $1 \mathrm{~cm}$ leads to a decrease in the number of weeds for 0.11 plants $\mathrm{m}^{-2}\left(\hat{\mathrm{y}} \mathrm{i}=23.77-0.11^{*} \mathrm{xi}\right)$ and the dry weed weight for $0.16 \mathrm{~g} \mathrm{~m}^{-2}$ ( $\left.\hat{\mathrm{y}} \mathrm{i}=34.86-0.16^{*} \mathrm{xi}\right)$. The dependencies between the parameters examined were very significant, which was determined by testing the obtained coefficients of simple linear correlation: the dependence of the number of weeds on the height stem $(r=-0.69)$ and the dependence of dry weight of weeds on the height stem $(r=-0.39)$. In the tests of some authors (Korres \& Froud-Williams 2002; Konvalina et al 2007; Hoad \& Davies 2008) it is affiliated that cultivars with high stem reduce the penetration of photosynthetic active radiation to lower levels, whereby the weeds become shadowed, and consequently their number and biomass decrease in relation to shorter cultivars of cereals. Thus, the shorter cultivars are less suitable for organic production (Mason et al 2007). Also, a negative correlation relationship between the number of weeds and the grain weight in the spike (- 0.32) was established, where the regression equation showed that by increasing the number of weeds per 1 plant $\mathrm{m}^{-2}$ the grain weight in the spike decreases by $0.04 \mathrm{~g}$ ( $\hat{\mathrm{y}} \mathrm{i}=1.999-1.041 * \mathrm{xi})$. By testing the linear correlation coefficient, a statistically significant dependence was found between these two parameters $(r=-0.32)$. In organic wheat production 
negative correlation of weed biomass with productive cereal properties has been determined (Mason et al 2007; Roljević Nikolić et al 2017).

Table 5- Correlation matrix of tested parameters

\begin{tabular}{|c|c|c|c|c|c|c|c|c|}
\hline $\begin{array}{l}\text { Weed } \\
\text { Parameters }\end{array}$ & $\begin{array}{l}\text { No. of } \\
\text { perennial } \\
\text { weeds }\end{array}$ & $\begin{array}{l}\text { No. of } \\
\text { annual } \\
\text { weeds }\end{array}$ & $\begin{array}{l}\text { No. of } \\
\text { weeds }\end{array}$ & $\begin{array}{l}\text { Dry weed } \\
\text { weight }\end{array}$ & $\begin{array}{l}\text { Stem } \\
\text { height }\end{array}$ & $\begin{array}{l}\text { Spike } \\
\text { length }\end{array}$ & $\begin{array}{l}\text { Weight } \\
\text { stem and } \\
\text { length }\end{array}$ & $\begin{array}{l}\text { Weight of } \\
\text { grains } \\
\text { per spike }\end{array}$ \\
\hline $\begin{array}{l}\text { No. of perennial } \\
\text { weeds }\end{array}$ & 1 & $0.37 * *$ & $0.27^{\mathrm{ns}}$ & $-0.04^{\mathrm{ns}}$ & $-0.11^{\mathrm{ns}}$ & $-0.15^{\mathrm{ns}}$ & $0.29^{\mathrm{ns}}$ & $0.22^{\text {ns }}$ \\
\hline $\begin{array}{l}\text { No. of annual } \\
\text { weeds }\end{array}$ & $0.37 * *$ & 1 & $0.30 *$ & $0.26^{\mathrm{ns}}$ & $-0.14^{\mathrm{ns}}$ & $0.03^{\mathrm{ns}}$ & $-0.25^{\mathrm{ns}}$ & $-0.27^{\mathrm{ns}}$ \\
\hline No. of weeds & $0.27^{\mathrm{ns}}$ & $0.30 *$ & 1 & $0.21^{\mathrm{ns}}$ & $-0.69 * *$ & $-0.05^{\mathrm{ns}}$ & $-0.23^{\mathrm{ns}}$ & $-0.32 *$ \\
\hline Dry weed weight & $-0.04^{\mathrm{ns}}$ & $0.26^{\mathrm{ns}}$ & $0.21^{\mathrm{ns}}$ & 1 & $-0.39 * *$ & $0.04^{\mathrm{ns}}$ & -0.11 & -0.13 \\
\hline Stem height & $-0.11^{\mathrm{ns}}$ & $-0.14^{\mathrm{ns}}$ & $-0.69 * *$ & $-0.39 * *$ & 1 & $0.17^{\mathrm{ns}}$ & $0.52 * *$ & $0.61 * *$ \\
\hline Spike length & $-0.15^{\mathrm{ns}}$ & $0.03^{\mathrm{ns}}$ & $-0.05^{\mathrm{ns}}$ & $0.04^{\mathrm{ns}}$ & $0.17^{\mathrm{ns}}$ & 1 & $-0.12^{\mathrm{ns}}$ & $-0.11^{\mathrm{ns}}$ \\
\hline $\begin{array}{l}\text { Weight stem and } \\
\text { length }\end{array}$ & $0.29^{\text {ns }}$ & $-0.25^{\mathrm{ns}}$ & $-0.23^{\mathrm{ns}}$ & $-0.11^{\mathrm{ns}}$ & $0.52 * *$ & $-0.12^{\mathrm{ns}}$ & 1 & $0.93 * *$ \\
\hline $\begin{array}{l}\text { Weight of grains } \\
\text { per spike }\end{array}$ & $0.22^{\mathrm{ns}}$ & $-0.27^{\mathrm{ns}}$ & $-0.32 *$ & $-0.13^{\mathrm{ns}}$ & $0.61 * *$ & $-0.11^{\mathrm{ns}}$ & $0.93 * *$ & 1 \\
\hline
\end{tabular}

$\operatorname{LSD} \alpha 0,05 / 2=1,96 ; \alpha 0,01 / 2=2,58$

\section{Conclusions}

The results of this study showed that in the organic alternative small grains production the use of proper fertilization and selection of the cultivars with adequate morphological and productive traits, might create significant influence on the number and dry weight of weeds, while the impact on the diversity of the weed community is negligible. In addition, the application of the examined fertilizer variants has a very positive effect on the studied morphological and productive properties of grain. A negative correlation between the stem height and the number (- 0.69) and dry weight of weeds (- 0.39) was established. Consequently, the smallest number $\left(13.7\right.$ plants $\left.\mathrm{m}^{-2}\right)$ and dry weight of weeds $(18.5 \mathrm{~g})$ were recorded in the spelt, which has the highest stem $(94.2 \mathrm{~cm})$ within the investigated cultivars. The obtained results indicate that the height stems has a significant contribution to the suppression of weeds. On the other hand, the weight of grains per spike depends on the number of weeds (- 0.32), which indicates that the mechanisms that contribute to control and suppression of weeds is of key importance for the establishment of stable production in organic agriculture.

\section{Acknowledgments}

Paper work is part of the project research 46006 ,Sustainable agriculture and rural development in function of Republic of Serbia strategic goals achievement within the Danube region” and 31066 „Modern breeding of small grains for present and future needs" financed by the Ministry of Education, Science and Technological Development Republic of Serbia

\section{References}

Andrew I K S, Storkey J \& Sparkes D L (2015). A review of the potential for competitive cereal cultivars as a tool in integrated weed management. Weed research 55(3): 239-248 
Andruszczak S, Kraska P, Kwiecinska-Poppe E \& Palys E (2012). Weed infestation of crops of winter spelt wheat (Triticum aestivum ssp. spelta) cultivars grown under different conditions of mineral fertilization and chemical plant protection. Acta Agrobotanica 65(3): 109-118

Blackshaw R E, Molnar L J \& Larney F J (2005). Fertilizer, manure and compost effects on weed growth and competition with winter wheat in western Canada. Crop Protect 24: 971-980

Garcìa-Martìn A, Lòpez-Bellido R J \& Coleto J M (2007). Fertilisation and weed control effects on yield and weeds in durum wheat grown under rain-fed conditions in a Mediterranean climate. Weed research 47:140-148

Hoad S, Topp C \& Davies K (2008). Selection of cereals for weed suppression in organic agriculture: A method based on cultivar sensitivity to weed growth. Euphytica $163: 355-366$

Jablonskytė-Raščè D, Maikštenienė S \& Mankevičienė A (2013). Evaluation of productivity and quality of common wheat (Triticum aestivum L.) and spelt (Triticum spelta L.) in relation to nutrition conditions. Zemdirbyste-Agriculture 100(1): 45-56

Jaćimović G, Malešević M, Marinković B, Crnobarac J, Latković D, Šeremešić S \& Milošev D (2008). Winter wheat yield and yield components depending on the level of nitrogen, phosphorus and potassium fertilization. Annals of agronomy 32(1): 57-63

Jornsgard B, Rasmussen K, Hill J \& Christiansen J L (1996). Influence of nitrogen on competition between cereals and their natursil weed populations. Weed Research 36(6): 461-470

Kaya Y \& Turkoz M (2016). Evaluation of genotype by environment interaction for grain yield in durum wheat using non-parametric stability statistics. Turkish Journal of Field Crops 21(1): 51-59

Koocheki A, Nassiri M, Alimoradi L \& Ghorbani R (2009). Effect of cropping systems and crop rotations on weeds. Agronomy for Sustainable Development 29: 401-408

Konvalina P, Stehno Z \& Moudrý J (2007). Testing of suitability of ideotype and varieties of wheat for organic and low input agriculture. Lucrări Ştiinţifice, Seria Agronomie 50: 241-247

Korres N E \& Froud-Williams R J (2002). Effects of winter wheat cultivars and seed rate on the biological characteristics of naturally occurring weed flora. Weed research 42(6): 417-428

Mason H E, Navabi A, Frick B L, O'Donovan J T \& Spaner D M (2007). The weed-competitive ability of Canada western red spring wheat cultivars grown under organic management. Crop science 47(3): 1167-1176

Pakize K U R T, Çifci E A, \& Yağdi K (2015). Ekmeklik buğday (Triticum aestivum L.)'da tane verimi ile bazı verim ögeleri arasındaki ilişkilerin saptanması. Tarım Bilimleri Dergisi 21(3): 355-362

Przystalski M, Osman A, Thiemt E M, Rolland B, Ericsson L, Østergård H, Levy L, Wolfe M, Büchse A, Piepho H P \& Krajewski P (2008). Comparing the performance of cereal varieties in organic and non-organic cropping systems in different European countries. Euphytica 163: 417-433

Roljević Nikolić S, Kovačević D, Cvijanović G, Dolijanović Ž \& Marinković J (2018). Grain yield and rhizosphere microflora of alternative types of wheat in organic production. Romanian Biotechnological Letters 23(1): 13301-13309

Roljević Nikolić S, Kovačević D \& Dolijanović Ž (2017). Floristic composition of weeds, morphological and productive characteristics of different wheat genotypes of alternative small grains in organic production. Journal of Agricultural Sciences 62(3): 229-240

Ross D M \& Van Acker R C (2005). Effect of nitrogen fertilizer and landscape position on wild oat (Avena fatua) interference in spring wheat. Weed Science 53(6): 869-876

Sans F X, Berner A, Armengot L \& Mader P (2011). Tillage effects on weed communities in an organic winter wheat-sunflowerspelt cropping sequence. Weed Research 51: 413-421

Szewczyk B F (2013). The influence of morphological features of spelt wheat (Triticum aestivum ssp. spelta) and common wheat (Triticum aestivum ssp. vulgare) varieties on the competitiveness against weeds in organic farming system. Journal of Food, Agriculture \& Environment 11(1): 416-421 
Vandeleur R K \& Gill G S (2004). The impact of plant breeding on the grain yield and competitive ability of wheat in Australia. Australian Journal of Agricultural Research 55(8): 855-861

Wolfe M S, Baresel J P, Desclaux D, Goldringer I, Hoad S, Kovacs G, Löschenberger F, Miedaner T, Østergård H \& Lammerts van Bueren E T (2008). Developments in breeding cereals for organic agriculture. Euphytica 163(3): 323-346

WRB I W G (2014). World Reference Base for Soil Resources 2014. International Soil Classification System For Naming Soils And Creating Legends For Soil Maps. World Soil Resources Report No. 106. FAO, Rome. Retrieved in March, 3, 2019 from http://www.fao.org/3/i3794en/I3794en.pdf

Zerner M C, Rebetzke G J \& Gill G S (2016). Genotypic stability of weed competitive ability for bread wheat (Triticum aestivum) genotypes in multiple environments. Crop and Pasture Science 67(7): 695-702

Zuk-Golaszewska K, Kurowski T, Zaluski D, Sadowska M \& Golaszewski J (2015). Physioagronomic performance of spring cultivars T. aestivum and T. spelta grown in organic farming system. International Journal of Plant Production 9(2): 211-236 